\title{
Monoterpene emission of Quercus suber L. highly infested by Cerambyx welensii Küster
}

\author{
Israel Sánchez-Osorio ${ }^{1}$ (1) $\cdot$ Gloria López-Pantoja $^{1} \cdot$ Raúl Tapias $^{1} \cdot$ Evangelina Pareja-Sánchez $^{2} \cdot$ Luis Domínguez $^{1}$
}

Received: 25 February 2019 / Accepted: 27 August 2019 / Published online: 18 October 2019

(C) INRA and Springer-Verlag France SAS, part of Springer Nature 2019

\begin{abstract}
- Key message Cork oaks highly infested by Cerambyx welensii emit an amount of limonene at dusk, when $C$. welensii adults become active. In contrast, emissions by neighboring cork oaks free of $C$. welensii are dominated by pinene-type compounds.

- Context The activity of the woodborer Cerambyx welensii Küster is a key factor in the decline of Quercus suber L. dehesas. - Aims This study aimed to estimate whether trees highly infested by $C$. welensii exhibited a peculiar emission profile, with known antennally active compounds.

- Methods Monoterpenes were sampled in situ in 2006 (day/late evening) and 2008 (early evening) from Q. suber stratified by whether or not trees were highly infested by $C$. welensii and analyzed by gas chromatography.

- Results Limonene, $\alpha$-pinene, $\beta$-pinene, sabinene, and myrcene accounted for over $87.2 \%$ of overall monoterpene emissions. Monoterpene composition and emission rates differed between the two groups, both during daytime and early evening, with a high presence of limonene in infested trees and dominance of pinene-type compounds in non-infested trees.

- Conclusion This work evidenced differences in foliar monoterpene emissions between $Q$. suber trees highly infested by C. welensii and non-infested trees, with a high presence of limonene in the former and dominance of pinene-type compounds in non-infested trees. We hypothesize that the detection - especially during the onset of insects daily flight — of certain compounds (e.g., limonene), together with the detection of specific ratios of several monoterpenes (e.g., those of limonene to pinenetype compounds), has a role in the intraspecific host selection by $C$. welensii.
\end{abstract}

Keywords Dehesa $\cdot$ Woodborer $\cdot$ Limonene $\cdot$ Pinene-type $\cdot$ Quercus decline

\section{Introduction}

Handling Editor: Aurélien Sallé

Contribution of the co-authors Project design, I. Sánchez-Osorio. Data collection, all authors. Data analysis and paper writing, I. SánchezOsorio. All authors read and approved the manuscript.

This article is part of the topical collection on Entomological issues during forest diebacks

Israel Sánchez-Osorio

isanchez@uhu.es

1 Departamento de Ciencias Agroforestales, ETSI La Rábida, University of Huelva, 21819 Palos de la Frontera, Huelva, Spain

2 Departament de Producció Vegetal i Ciència Forestal (EEAD-CSIC Associated Unit), University of Lleida, Lleida, Spain
Open Mediterranean woodlands (called dehesas in Spain) are outstanding agroforestry systems, protected under the European Habitats Directive (Council Directive 92/43/EEC). There are 4 million ha of this type of woodlands in the western Iberian Peninsula, with Quercus suber L. the dominant tree species covering 716,000 ha in Portugal and 300,000 ha in Spain; together, these areas produce about two-thirds of the world cork production (Alejano et al. 2011; ICNF 2013). Cork oak stands are threatened by multiple stresses, both anthropogenic and natural (Aronson et al. 2009), being the activity of woodboring insects, such as Cerambyx welensii Küster, the key factor in the decline of $Q$. suber in south-west Spain (Sallé et al. 2014; Tiberi et al. 2016; Torres-Vila et al. 2017). C. welensii is a 
large (up to $60 \mathrm{~mm}$ long) cerambycid that affects several deciduous trees, mainly within the Quercus genus (Vives 2000). The flight period of $C$. welensii spans from mid-May to late-July. Adults become active at dusk, with peak adult activity occurring mainly between 21:00 and 24:00 h (Lpez-Pantoja et al. 2008; data of the authors), though there are also reports of adult activity during the daytime (Vives 2000; Torres-Vila et al. 2016). Adverse impact of $C$. welensii adults on tree health has not been reported; however, larvae bore into wood causing tree branches and trunks to break (Lpez-Pantoja et al. 2008) and facilitate infection by plant pathogens and wood-decaying fungi (Martín et al. 2005).

Terpenes and other volatile organic compounds play important roles in both plant physiology and interactions of plants with their environment, e.g., protecting plants against stressors or acting as a mechanism for interplant communication (Loreto et al. 2014). There is considerable evidence that longhorn beetles are attracted to volatiles, such as monoterpenes, emitted by plants. In some species, host volatiles synergize response to sex pheromones (Allison et al. 2004; Millar and Hanks 2017). Little is known, however, about the role of such compounds in host location by wood-boring beetles that infest non-coniferous trees (see, for example, Millar and Hanks 2017). Among oaks, Q. suber has been widely reported to be a strong monoterpene emitter (Staudt et al. 2004; Pio et al. 2005; Lavoir et al. 2011), its emissions showing both seasonal and site variations that can be attributed to microclimate conditions (Staudt et al. 2004) as well as genetic diversity (Staudt et al. 2004; Loreto et al. 2014). In addition, biotic and environmental stresses may affect monoterpene emission, since monoterpene precursors are derived from photosynthetic activity (Núñez et al. 2002; Lavoir et al. 2011). Despite this variability, the emission profile of a given Q. suber tree is considered to be relatively stable (Staudt et al. 2004), consisting of four dominant monoterpenes: $\alpha$ pinene, $\beta$-pinene, sabinene, and limonene, and a minor presence of myrcene (Staudt et al. 2004; Pio et al. 2005; Lavoir et al. 2011).

Observations indicate that $C$. welensii prefers to colonize weak, damaged, or old trees and that visual cues play a role in host location (Lpez-Pantoja et al. 2008; Torres-Vila et al. 2017). In addition, the cork harvesting (every 9 years in south-west Spain) frequently causes bark damage to trees, facilitating oviposition of $C$. welensii as well as triggering the release of volatiles that may be attractive to $C$. welensii (Snchez-Osorio et al. 2016). Moreover, interannual presence of large numbers of $C$. welensii on the same trees and aggregation phenomena in trees showing bark exudates have been reported (Lpez-Pantoja et al. 2008). In field experiments, C. welensii has been found to be attracted to traps baited with a mixture of red wine, vinegar, and sugar (Torres-Vila et al. 2012) or with synthetic volatiles mimicking fermenting plant material (Snchez-Osorio et al. 2016). C. welensii antennae respond to limonene, myrcene, and pinene-type compounds (Sánchez-Osorio 2005), and field catches obtained with synthetic volatiles at a low release rate $\left(1.2 \mathrm{~g} \mathrm{day}^{-1}\right)$ slightly improved when $\beta$-pinene was added to the bait (SnchezOsorio et al. 2016).

The aim of this study was to find out whether the foliar emissions of monoterpenes by $Q$. suber mediate intraspecific host selection by $C$. welensii. For this purpose, we analyzed monoterpene emission during daytime, early evening, and late evening by $Q$. suber trees stratified by whether they were or not highly infested by $C$. welensii. Time spans studied were chosen according to the daily flight activity of $C$. welensii, including the early evening. We hypothesized that (i) the monoterpene emission of $Q$. suber would exhibit small-scale spatial and temporal variations and (ii) there would be a relationship between emission patterns and infestation by C. welensii. Identification of the factors related to host recognition, in particular, volatile compounds released by trees, might facilitate the development of lures and ultimately sustainable pest management strategies, for example, the use of baited traps for detection, monitoring, and, eventually, mass trapping of adults.

\section{Materials and methods}

\subsection{Plant material}

Foliar monoterpene samples were collected in 2006 and 2008 in a dehesa located in south-west Spain $\left(37^{\circ} 15^{\prime} 43.73^{\prime \prime} \mathrm{N}, 6^{\circ}\right.$ $28^{\prime} 34.65^{\prime \prime} \mathrm{W}, 80 \mathrm{~m}$ a.s.1.) strongly affected by $C$. welensii and composed primarily of $Q$. suber trees (density of 75 trees ha ${ }^{-1}$; mean perimeter at breast height was 168.4 and $131.1 \mathrm{~cm}$, infested and non-infested trees, respectively). The mean temperature for June was similar in both years $\left(23^{\circ} \mathrm{C} \pm 0.6\right)$, while the annual precipitation was $819 \mathrm{~mm}$ in 2006 (with $30 \mathrm{~mm}$ of rainfall in June) and $588 \mathrm{~mm}$ in 2008 (with no measurable rainfall in June) (Almonte meteorological station $37^{\circ} 08^{\prime} 53^{\prime \prime}$ $\left.\mathrm{N}, 6^{\circ} 28^{\prime} 35^{\prime \prime} \mathrm{W}\right)$.

We studied 12 trees in 2006, and the same 12 plus an additional 24 (total of 36 trees) in 2008. Based on both sightings of $C$. welensii adults on each tree between 2002 and 2007 (Lpez-Pantoja et al. 2008) and the presence of symptoms that could indicate colonization by $C$. welensii larvae (exit holes and sawdust), two groups of trees were established each year. The first group ( $n=9$ in 2006; $n=18$ in 2008), hereafter referred to as infested trees, was composed of the trees with the higher occurrence of adults (mean of $54 \pm 23$ insects per tree between 2002 and 2007). These trees also showed the greatest amount of damage by large woodborers and systematically showed symptoms that could indicate colonization by $C$. welensii larvae, though the presence of larvae was not verified. The second group ( $n=3$ in 2006; $n=18$ in 
2008), hereafter referred to as non-infested trees, was composed of neighboring $Q$. suber on which neither adults, nor damage, nor symptoms attributable to this woodborer were observed (and this also stands after a survey carried out in 2008).

Monoterpene volatiles were collected in the field from intact twigs (two twigs per tree) in 2006 and from pruned twigs (one twig per tree, sampled immediately after pruning) in 2008. All twigs sampled ( $30 \mathrm{~cm}$ long, 53-187 leaves; mean dry weight of $6.2 \pm 2.3 \mathrm{~g}$ in 2006 and $14.48 \pm 0.7 \mathrm{~g}$ in 2008) were selected from near the tip of sun-exposed branches, at a height of $\approx 2 \mathrm{~m}$, and in the 2006 samplings, the pairs of twigs from the same tree were $1 \mathrm{~m}$ apart.

\subsection{Monoterpene sampling and analysis}

Based on flight period estimates by Lpez-Pantoja et al. (2008) for $C$. welensii in the studied dehesa habitat, monoterpenes were sampled near the peak of the $C$. welensii flight period each year. In 2006, volatiles were sampled during two different periods: the daytime period (13:00 to $14: 30 \mathrm{~h}$, June 12 ) close to the daily peak of $Q$. suber emissions (Pio et al. 2005), and the late evening period (21:30 to 23:00 h, June 13), from the same twigs as those studied on 12 June, during the peak activity of $C$. welensii adults (Lpez-Pantoja et al. 2008). To study short-term variations in monoterpene emissions during a prior period that included the onset of $C$. welensii daily flight, in 2008, samples were collected five times over the early evening period $(19: 00,19: 35,20: 10,20: 45$, and 21:20 h, June 24). For this purpose, three to four different trees from each study group were randomly selected for analysis in each measurement time (Table 1).

Monoterpenes were sampled using a custom-made headspace collection system with bag enclosure (Maja et al. 2014), based on the "aeration system" described by Zhang et al. (1999). Each collection system consisted of two Teflon sampling lines connected to a diaphragm pump (SP 200 EC-LC; Schwarzer Precision, Essen, Germany); the two lines allowed for simultaneous collection of a sample from a twig and a blank control sample (from a measurement chamber in which no twig had been enclosed). The measurement chambers

Table 1 Factorial treatment combinations and number of replicates, to study short-term monoterpene emissions of Quercus suber trees over the early evening period

\begin{tabular}{lllllll}
\hline Infestation & \multicolumn{5}{l}{ Measurement time (h) } \\
\cline { 2 - 7 } & $19: 00$ & $19: 35$ & $20: 10$ & $20: 45$ & $21: 20$ & Total \\
\hline Infested & 4 & 4 & 3 & 4 & 3 & 18 \\
Non-infested & 3 & 4 & 4 & 3 & 4 & 18 \\
Total & 7 & 8 & 7 & 7 & 7 & 36 \\
\hline
\end{tabular}

consisted of $38 \mathrm{~cm} \times 25 \mathrm{~cm}$ polyester oven bags (Albal, Cofresco, Madrid, Spain). Each twig sampled was enclosed in a new measurement chamber, with the bag opening fastened around the stem with garden wire; a Teflon air-inlet attached to a charcoal filter glass tube (Split Vent Trap containing $1.2 \mathrm{~g}$ charcoal; Cromlab, Barcelona, Spain) allowed air to enter the chamber. Monoterpenes were trapped by drawing the air inside each bag through a glass sorbent tube $(150 \mathrm{mg}$ 403 Orbo Tenax TA tube, 60/80 mesh; Sigma-Aldrich, Madrid, Spain) for $5 \mathrm{~min}$ at a flow rate of $120 \mathrm{ml} \mathrm{min}^{-1}$. All sample tubes were sealed with Teflon caps immediately after collection, kept at $\approx 4{ }^{\circ} \mathrm{C}$ and taken to the laboratory where samples were stored at $-28^{\circ} \mathrm{C}$ until analysis (in the following 24-48 h). Temperature and relative humidity, besides photosynthetic photon flux density $(P P F D)$ in 2008 , were monitored during samplings.

Sample tubes were spiked with 1-bromo-2-chlorobenzene as an internal standard and eluted with $1.5 \mathrm{ml}$ cyclohexane (purity $>99.5 \%$ and $>99 \%$, respectively; Sigma-Aldrich, Madrid, Spain). Monoterpene analyses were performed with $1-\mu l$ aliquots of the cyclohexane solution either by gas chromatography-mass spectrometry (GC-MS) (GC type 6890N, MSD 5973; Agilent, Santa Clara, USA) in 2006 or by gas chromatography with a flame ionization detector (Agilent 6890N GC system) in 2008. In both cases, an HP5MS column $(0.25 \mathrm{~mm} \times 30 \mathrm{~m} \times 0.25 \mu \mathrm{m})$ using helium as the carrier gas $\left(1 \mathrm{ml} \mathrm{min}^{-1}\right)$ was employed, and the oven temperature was programmed with the following conditions: the initial temperature $\left(46^{\circ} \mathrm{C}\right)$ was increased at $30^{\circ} \mathrm{C} \mathrm{min}^{-1}$ to $70^{\circ} \mathrm{C}$, held steady for $4 \mathrm{~min}$, and then increased at rates of $5{ }^{\circ} \mathrm{C} \mathrm{min}{ }^{-1}$ to $80^{\circ} \mathrm{C}, 4.5^{\circ} \mathrm{C} \mathrm{min}^{-1}$ to $90{ }^{\circ} \mathrm{C}$, and $50{ }^{\circ} \mathrm{C} \mathrm{min}{ }^{-1}$ to $300^{\circ} \mathrm{C}$.

Peaks were identified by comparison with pure standards (Sigma-Aldrich; Madrid, Spain; purity $\geq 94 \%$ ) and with mass spectra in the NIST 02 library (MSD Chemstation Build 75 software). For quantitative analysis, calibration curves were determined for $\alpha$-pinene, $\beta$-pinene, sabinene, limonene, and myrcene (0.05-1 ppm solutions). The calibration curves were highly significant $\left(R^{2}>0.99\right)$ in all cases. Emission rates were calculated in nanograms of compound per gram of dry weight of leaf material per hour (ng gdw ${ }^{-1} \mathrm{~h}^{-1}$ ), after subtracting the values measured in blank chambers. We analyzed only the monoterpenes, other volatile compounds (leaf alcohols, sesquiterpenes, etc.) that may have been emitted by the foliage not being considered here.

\subsection{Statistical analyses}

Comparative analyses of monoterpene emissions were performed using linear mixed models (LMMs, lme4 package; Bates et al. 2014), for the total emission variable $\left(T_{\mathrm{em}}\right.$, the sum of the five main compounds: $\alpha$-pinene, $\beta$-pinene, sabinene, limonene, and myrcene), and for each of the main 
monoterpenes separately. Mean monoterpene emission was treated as the dependent variable (the emission from each tree in 2006 being the mean of values obtained from the two twigs studied). Infestation by $C$. welensii (used as a class variable) and measurement time (for the 2008 dataset) were used as fixed factors (Table 2). Tree identity (intercept model) was included as a random factor. The significance of the main factors was assessed using likelihood ratios. For multiple testing, Benjamini-Hochberg adjusted $P$ values were used (lsmeans package; Lenth 2014). Within-tree repeatability of emissions (intraclass correlation, $r$ ) (Falconer and Mackay 1996) was analyzed both between twigs from each tree and over time.

We performed permutational multivariate analysis of variance (PERMANOVA, using the Bray-Curtis dissimilarity index and 999 permutations) and multivariate dispersion analysis (vegan package; Oksanen et al. 2015) to determine whether there were differences in emission composition between trees infested by $C$. welensii and trees not infested by this woodborer. The variables included in the PERMANOVA were individual relative emissions (percentage of $T_{\mathrm{em}}$ ) for limonene and myrcene, as well as a newly created variable (called pinene-type) corresponding to the sum of relative emissions for $\alpha$-pinene, $\beta$-pinene, and sabinene. This pinene-type variable could aid us to differentiate a pinene-type emission profile, as $\alpha$-pinene, $\beta$-pinene, and sabinene are highly correlated (positive) in Q. suber (Staudt et al. 2004). Loglikelihood ratio tests (G-tests) (with Williams' correction) were used to determine whether the percentage of trees with a limonene profile differed between infested and non-infested $Q$. suber.

Table 2 Leaf monoterpene emissions (mean $\pm \mathrm{SE}$ ), expressed as total monoterpene emission rate $\left(T_{\mathrm{em}}\right.$, the emission of the five main monoterpenes pooled), individual monoterpene relative emission, and
All statistical analyses were performed in R software, version 3.1.0, using $\alpha=0.05$ and $\alpha=0.1$ as the thresholds for significance and marginal significance, respectively.

\section{Results}

\subsection{Monoterpene emission by Quercus suber leaves}

The air temperature $(T)$ was high across the three sampling times, especially throughout 2006 daytime and 2008 early evening samplings $\left(>28.1^{\circ} \mathrm{C}\right)$. Relative humidity $(\mathrm{RH})$ was very low across those two sampling periods ( $<40 \%$ overall). Further, the photosynthetic photon flux density (PPFD) sharply decreased over the 2008 early evening sampling (from 1097 to $75 \mu \mathrm{mol} \mathrm{m} \mathrm{m}^{-2} \mathrm{~s}^{-1}$ ) and reached values under $45 \mu \mathrm{mol} \mathrm{m} \mathrm{s}^{-2}$ in the 2006 late evening sampling (Fig. 1).

The main monoterpenes emitted by $Q$. suber in 2006 and 2008 were limonene, $\alpha$-pinene, $\beta$-pinene, sabinene, and myrcene (Table 1; Fig. 2); these five compounds accounted for 87.2 to $95.6 \%$ of the overall monoterpene emission by each tree (2006 daytime and 2008 early evening, respectively) but accounted for $100 \%$ of all monoterpenes detected from five infested trees and one non-infested tree in the 2006 late evening sampling. During the 2006 late evening sampling, two infested trees and one non-infested tree showed no measurable emissions. Low emissions $(\leq 2 \%$ of the overall emission by each tree in 2006 daytime, and traces in both 2006 late evening and 2008 early evening samples) were found for cineole, camphene, $\gamma$ terpinene, $\alpha$-terpinene, $\rho$-cymene, $\alpha$-phellandrene, and $\alpha$ thujene. Given these results, only the emissions of limonene, $\alpha$-pinene, $\beta$-pinene, sabinene, and myrcene were considered

abundance of trees with a limonene-type profile, of Quercus suber trees in 2006 and 2008 in south-west Spain. Trees were stratified by whether or not they were infested by Cerambyx welensii

\begin{tabular}{|c|c|c|c|c|c|c|c|}
\hline \multirow{2}{*}{$\begin{array}{l}\text { Samp }^{\#} \\
\text { infestation }\end{array}$} & \multirow{2}{*}{$\begin{array}{l}\text { Total emission rate }\left(T_{\mathrm{em}},\right. \\
\left.\text { ng gdw }^{-1} \mathrm{~h}^{-1}\right)\end{array}$} & \multicolumn{5}{|c|}{ Emission composition $($ sum $=100 \%)$} & \multirow{2}{*}{$\begin{array}{l}\text { Limonene profile* (\% } \\
\text { trees) }\end{array}$} \\
\hline & & $\alpha$-Pinene & $\beta$-Pinene & Sabinene & Myrcene & Limonene & \\
\hline \multicolumn{8}{|c|}{ Daytime (12 June 2006; 13:00-14:30 h) } \\
\hline Infested & $1950.22 \pm 339.06 \mathrm{a}$ & $12.5 \pm 1.6 \mathrm{a}$ & $9.3 \pm 1.2 \mathrm{a}$ & $22.7 \pm 2.7 \mathrm{a}$ & $7.1 \pm 0.4 \mathrm{a}$ & $48.4 \pm 5.0 \mathrm{a}$ & 88.9 \\
\hline Non-infested & $1510.21 \pm 541.74 \mathrm{a}$ & $22.4 \pm 2.5 b$ & $17.1 \pm 1.2 \mathrm{~b}$ & $43.9 \pm 2.8 b$ & $5.3 \pm 0.5 \mathrm{a}$ & $11.3 \pm 5.9 b$ & 0 \\
\hline \multicolumn{8}{|c|}{ Late evening (13 June 2006; 21:30-23:00 h) } \\
\hline Infested & $26.73 \pm 2.92 \mathrm{a}$ & $22.4 \pm 13.9 \mathrm{a}$ & $2.5 \pm 2.5 \mathrm{a}$ & $1.8 \pm 1.8 \mathrm{a}$ & 0 & $73.3 \pm 15.1 \mathrm{a}$ & 85.7 \\
\hline Non-infested & $25.22 \pm 2.61 \mathrm{a}$ & $22.7 \pm 19.1 \mathrm{a}$ & $0 \mathrm{a}$ & $0 \mathrm{a}$ & 0 & $77.3 \pm 19.1 \mathrm{a}$ & 66.6 \\
\hline \multicolumn{8}{|c|}{ Early evening (24 June 2008; 19:00-21:20 h) } \\
\hline Infested & $962.01 \pm 197.06 \mathrm{a}$ & $11.2 \pm 3.1 \mathrm{a}$ & $6.4 \pm 2.2 \mathrm{a}$ & $15.9 \pm 4.1 \mathrm{a}$ & $0.7 \pm 0.4 \mathrm{a}$ & $65.8 \pm 8.5 \mathrm{a}$ & 88.9 \\
\hline Non-infested & $1209.52 \pm 562.06 \mathrm{a}$ & $21.2 \pm 5.1 \mathrm{a}$ & $6.3 \pm 1.9 \mathrm{a}$ & $19.6 \pm 5.1 \mathrm{a}$ & $0.5 \pm 0.2 \mathrm{a}$ & $52.5 \pm 10.4 \mathrm{a}$ & 58.8 \\
\hline
\end{tabular}

Different letters indicate significant differences by infestation status within each sampling time (LMM followed by likelihood ratio tests. $\alpha=0.05$ )

\# Sampling time

*Limonene percentage $>30 \%$ of $T_{\mathrm{em}}$ (Staudt et al. 2004) 
Fig. 1 Air temperature $(T)$, relative humidity $(R H)$, and photosynthetic photon flux density $(P P F D)$ during sampling of monoterpene emissions from Quercus suber in 2008

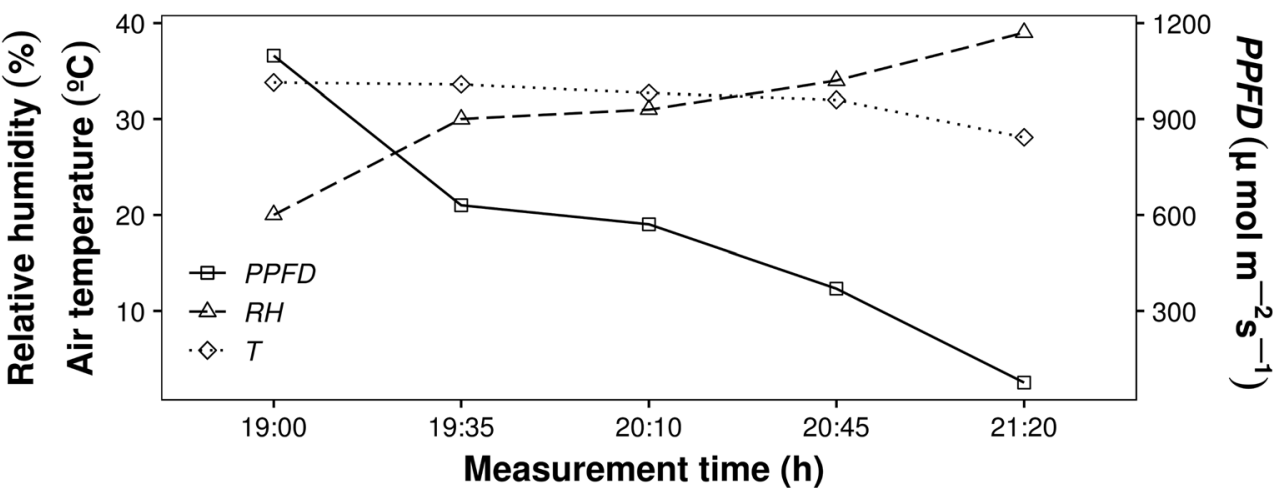

for further statistical analysis, and thereafter, the $T_{\mathrm{em}}$ variable refers to the sum of observed emissions of these five compounds. Within-tree repeatability of monoterpene relative emissions (intraclass correlation, $r$ ) was high both between twigs from each tree in daytime samples ( $r$ ranging from 0.91 to $0.98, \alpha$-pinene and limonene, respectively) and between 2006 daytime and 2008 early evening samples ( $r$ ranging from 0.62 to $0.94, \alpha$-pinene and limonene, respectively). In contrast, repeatability of emission rates was low ( $r<0.3$ overall) between twigs from each tree, as did over both short-time (in 2006) and long-time (between 2006 daytime and 2008 early evening samples) periods.

The $T_{\mathrm{em}}$ variable reached a mean of $1840.2 \mathrm{ng} \mathrm{gdw}^{-1} \mathrm{~h}^{-1}$ in the 2006 daytime sampling and ranged between 190 and $2450 \mathrm{ng} \mathrm{gdw}^{-1} \mathrm{~h}^{-1}$ (21:20 and 20:10 h, respectively) in the 2008 early evening sampling; furthermore, $T_{\mathrm{em}}$ was very low in the 2006 late evening sampling (average of $26 \mathrm{ng} \mathrm{gdw}^{-1} \mathrm{~h}^{-1}$ ). The overall emission composition of trees showed a greater presence of limonene in both early and late evening than daytime emissions (Table 1). Short-term changes over the early evening period in 2008 were found to be significant for both $T_{\mathrm{em}}$ and $\alpha$ pinene emissions (Table 3 ), the highest values being found at 20:10 (Fig. 3a-e). The emission profile of all 12 trees analyzed in the 2006 daytime sampling remained the same in the 2008 early evening sampling. Furthermore, seven out of nine trees had the same emission profile in the two 2006 samplings.

\subsection{Comparing foliar monoterpene emission between Quercus suber highly infested and not infested by Cerambyx welensii}

The limonene chemotype was the most abundant in trees highly infested by $C$. welensii overall ( 85.7 to $88.9 \%$ of trees, depending on the sampling time) (Table 1). None of the trees not infested by C. welensii showed the limonene chemotype in the daytime sampling, and this profile was less common in these trees than in trees highly infested by $C$. welensii in the early evening $(58.8 \%)$ and late evening (66.6\%) samplings (G-test: $G_{1}=4.06, P=0.04$; $G_{1}=0.34, P=0.56$, respectively). Differences in individual monoterpene relative emissions between the two study groups were significant only in the 2006 daytime sampling (Table 1, Fig. 1). Specifically, infested trees had both lower percentages of the three pinene-type compounds (1.85 times on average; LMM: $\chi_{1}^{2} \geq 4.89, P \leq 0.03$, for all three compounds) and higher percentages of limonene (4.28 times; LMM: $\chi^{2}{ }_{1}=6.27, P=0.01$ ) than non-infested trees. Differences in emission composition (relative emissions for limonene, myrcene, and pinene-type compounds together) between the two study groups were significant in the 2006 daytime and 2008 early evening samplings (PERMANOVA: $F_{1}=5.14, P=0.04$ and $F_{1}=4.45, P=0.03$, respectively) but not in 2008 late evening sampling $\left(F_{1}=0.02\right.$, $P=0.94)$.
Fig. 2 Representative chromatogram of foliage monoterpenes from two Quercus suber trees, one highly infested by Cerambyx welensii, and another one not infested by this woodborer. Compounds identified: (1) $\alpha$-thujene; (2) $\alpha-$ pinene; (3) camphene; (4) sabinene; (5) $\beta$-pinene; (6) myrcene; (7) $\alpha$-phellandrene; (8) limonene; (9) cineol; (10) ocimene; (11) $\gamma$-terpinene

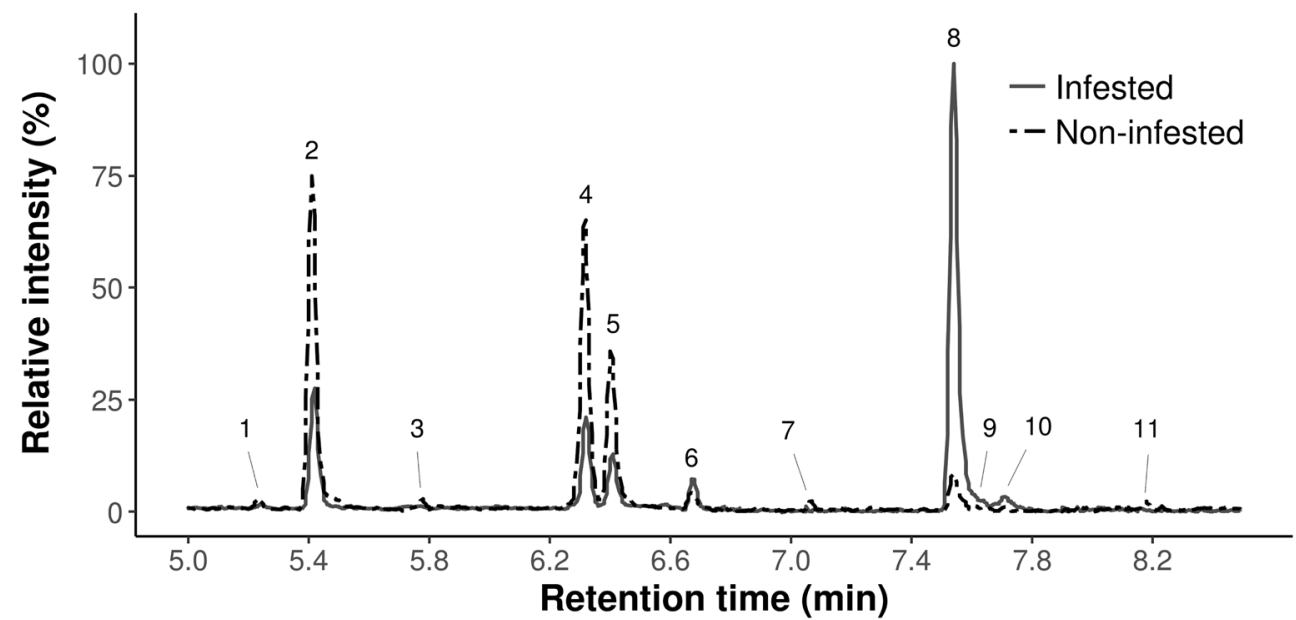

INRA פ⿴囗 Springer 
Table 3 Linear mixed model results ( $P$ values only) of individual monoterpene and total monoterpene emissions $\left(T_{\mathrm{em}}\right.$, the emission of the five main monoterpenes pooled) of Quercus suber trees over the early evening (19:00-21:20 h) in 2008, for main effects of measurement time and infestation by Cerambyx welensii

\begin{tabular}{|c|c|c|c|c|c|c|}
\hline \multirow[b]{2}{*}{ Source } & \multicolumn{6}{|c|}{$P$ values } \\
\hline & $\begin{array}{l}\alpha- \\
\text { Pinene }\end{array}$ & Sabinene & $\begin{array}{l}\beta- \\
\text { Pinene }\end{array}$ & Myrcene & Limonene & Total $\left(T_{\mathrm{em}}\right)$ \\
\hline Measurement time & 0.02 & 0.09 & 0.07 & 0.14 & 0.25 & 0.03 \\
\hline Infestation & 0.93 & 0.83 & 0.77 & 0.93 & 0.05 & 0.21 \\
\hline Measurement time $\times$ infestation & 0.03 & 0.03 & 0.01 & 0.57 & 0.20 & 0.53 \\
\hline
\end{tabular}

$P$ values $<0.1$ are shown in italics

The overall $T_{\mathrm{em}}$ values obtained from all three sampling times showed no significant differences between the two study groups (LMM: $\chi^{2}{ }_{1} \leq 1.56, P \geq 0.15$ ) (Table 1 and Fig. $3 f$ ). Limonene emissions from infested trees significantly exceeded that of non-infested trees in the 2006 daytime (943.4 $\mathrm{ng} \mathrm{gdw}^{-1} \mathrm{~h}^{-1}$ and $170.6 \mathrm{ng} \mathrm{gdw}^{-1} \mathrm{~h}^{-1}$, respectively; LMM: $\left.\chi_{1}^{2}=14.23, P<0.001\right)$ and the 2008 early evening sampling (546.3 $\mathrm{ng} \mathrm{gdw}^{-1} \mathrm{~h}^{-1}$ and $237.4 \mathrm{ng} \mathrm{gdw}^{-1} \mathrm{~h}^{-1}$, respectively; LMM: $\chi^{2}{ }_{1}=3.59, P=0.05$ ) (Fig. 3f). Further, there was a significant measurement time $\times$ infestation interaction effect on the emission of the three pinene-type compounds in 2008 (Table 3), the largest difference in summed emissions of the three compounds (32.2 times higher in noninfested trees) being observed at 19:35 h (Fig. 3b).

\section{Discussion}

Plants invest a great deal in volatile terpene production and emission, and multiple stresses affect both constitutive and induced volatile emissions, influencing plant-insect relationships (Loreto et al. 2014; Maja et al. 2014). The ecological function of both volatile production and intraspecific diversification (presence of chemotypes) is not well understood, though the latest research suggests an indirect role in improving thermotolerance and protection against oxidants (Niinemets et al. 2013; Loreto et al. 2014). Under summer conditions, we found differences in foliar monoterpene emission between $Q$. suber trees highly infested by the woodborer C. welensii and neighboring non-infested trees, in terms of both emission rate and composition. The differences were found both in the daytime and the early evening periods, with a high presence of limonene in emissions by infested trees and pinene-type compounds dominating emissions by noninfested trees.

The main foliar monoterpenes we found from $Q$. suber were limonene, $\alpha$-pinene, $\beta$-pinene, sabinene, and myrcene (accounting on average for 87.2 to nearly $100 \%$ of the total emissions). The same five compounds have previously been found in other regions to represent up to $90 \%$ of total emissions from Q. suber (Staudt et al. 2004; Pio et al. 2005). Poor soil water availability, high temperatures, and low relative humidity, conditions that are common during summer in the south of the Iberian Peninsula, may determine physiological responses of vegetation that affect monoterpene emission (Niinemets et al. 2002; Lavoir et al. 2011). In Spain, environmental conditions similar to those we found during our sampling periods $\left(T, 33.5-40.5^{\circ} \mathrm{C} ; R H,<40 \%\right)$ caused a drop in Q. ilex emissions (Núñez et al. 2002). Under summer conditions, we observed low daytime emission rates (on average, $1.84 \mu \mathrm{g} \mathrm{gdw}^{-1} \mathrm{~h}^{-1}$ ) that were within the range of 1 to $5 \mu \mathrm{gdw}^{-1} \mathrm{~h}^{-1}$ previously reported from $Q$. suber (Pio et al. 2005) and Q. ilex (Núñez et al. 2002). A high occurrence of the genotype-dependent limonene chemotype (up to $62 \%$ of trees) has been reported in Q. suber (Staudt et al. 2004). In our results, the limonene profile was found in $<67 \%$ in $Q$. suber trees not infested by $C$. welensii but was much more common in trees infested by $C$. welensii ( $>85 \%$ of trees, regardless of the year and sampling time).

Stress-associated changes in emission may occur even on a relatively short time scale of days to hours (Pio et al. 2005; Loreto et al. 2014). Moreover, during the early evening and late evening periods, selected for their relevance to $C$. welensii behavioral patterns, emission rates were probably affected by low $P P F D$ values. The low repeatability estimates we found for measured emission rates could suggest that they were affected by short-term environmental and physiological constraints (e.g., light, temperature, photosynthesis); in contrast, the high within-individual repeatability in emission composition we found could be attributable to systematic factors (e.g., genotype, constant environmental conditions, and physiological status of trees). Across the early evening period, differences we found in the effect of measurement time on the emissions of pinene-type compounds and limonene could suggest a higher dependence of the former on variables such as temperature, light, or water stress (Núñez et al. 2002; Grote 2007). Physicochemical characteristics of monoterpenes (solubility, volatility, and diffusivity) can control emissions and interact with physiological limitations (Niinemets et al. 2013). The increase in the relative contribution of limonene to 

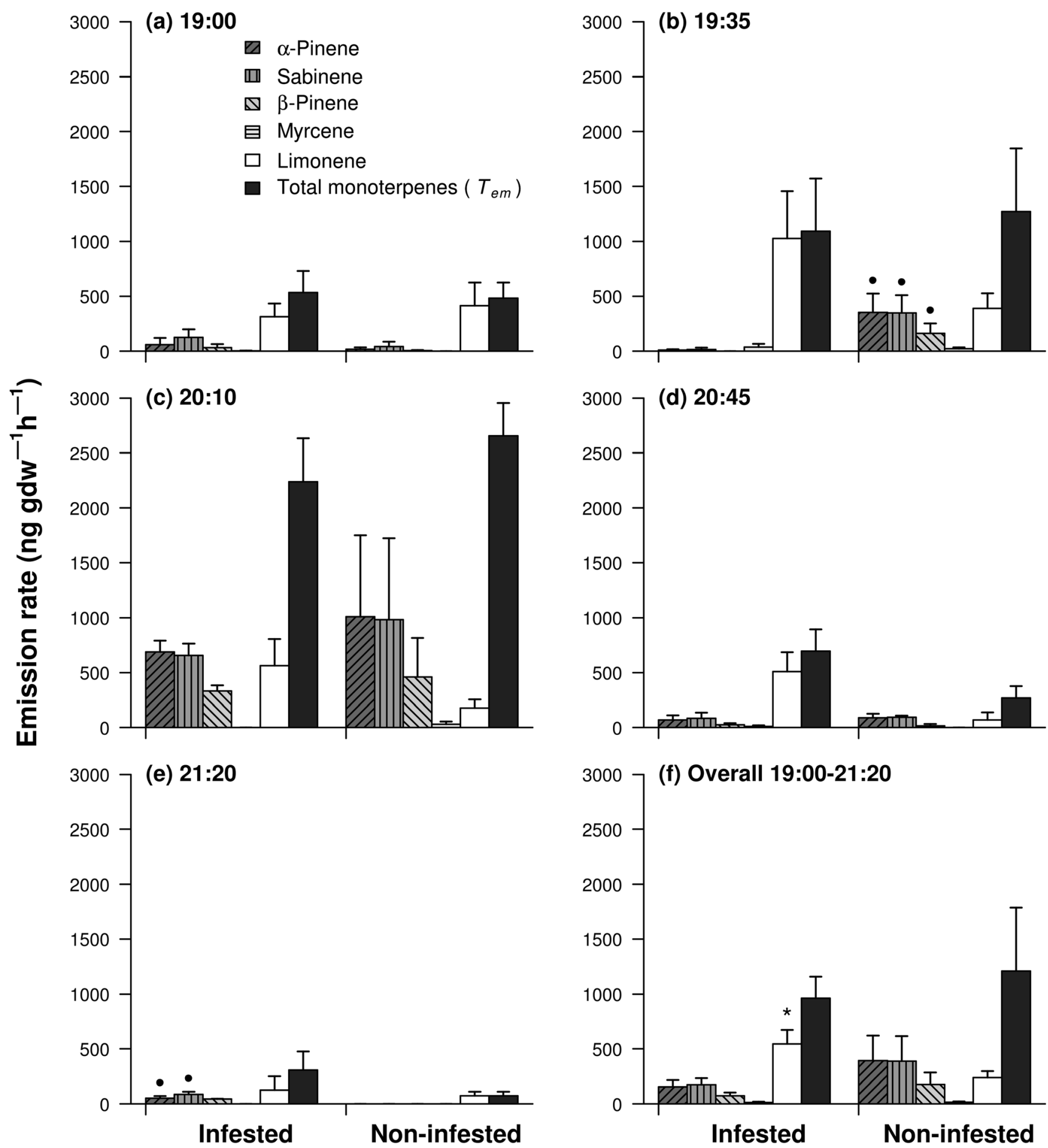

Fig. 3 Short-term variation, during 2008 early evening, in the mean ( \pm $\mathrm{SE})$ emission rates $\left(\mathrm{ng} \mathrm{gdw}{ }^{-1} \mathrm{~h}^{-1}\right)$ of individual monoterpenes and total monoterpene emission ( $T_{\mathrm{em}}$, the emission of the five compounds pooled) from Quercus suber stratified by whether or not trees were infested by

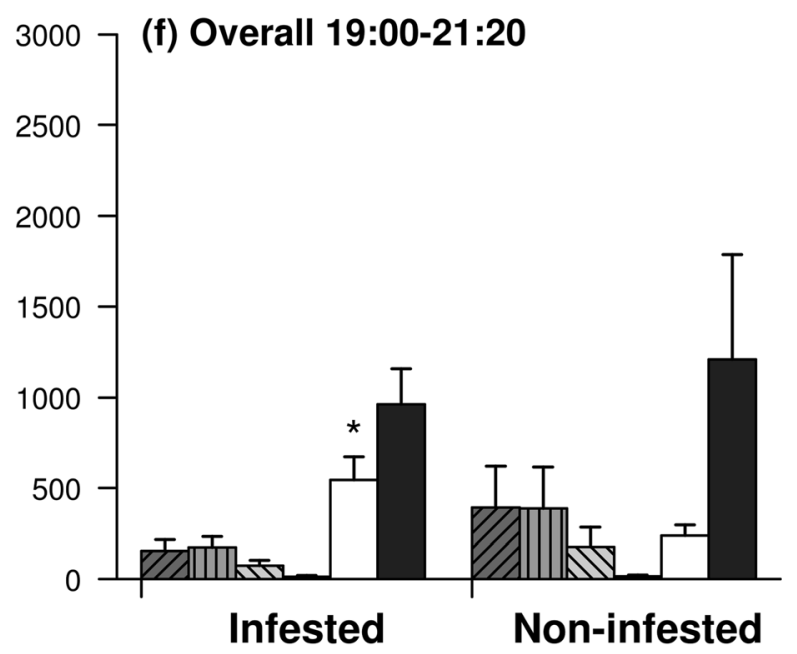

Cerambyx welensii. For each measurement time (panels a-f),, a symbol over a bar denotes significant differences between trees with different infestation status $\left(^{*}, P<0.05 ; \cdot, P<0.1\right.$. LMM with Benjamini-Hochberg correction. $n=3-4$ per measurement time for each infestation status)

Q. suber emissions during the early hours of the night has been explained by storage of a certain amount of it inside leaves, together with its low volatility compared with pinene-type compounds (Pio et al. 2005). It has been suggested that non-stored constitutive volatiles play a role in the mitigation of some abiotic stresses, by stabilizing membranes and serving as antioxidants (see, for example, Niinemets et al. 2013). Nevertheless, the role of monoterpenes, especially limonene, and other isoprenoids in such defense mechanisms remains unclear (Loreto et al. 2014). 
Volatile chemicals released by damaged or stressed host plants may provide cues that cerambycids use to locate larval hosts (Allison et al. 2004; Millar and Hanks 2017), and visual cues could also influence host choice (Torres-Vila et al. 2017); however, the underlying host-selection mechanisms by longhorned wood-boring beetles remain poorly understood. In our study area, Lpez-Pantoja et al. (2008) reported a continuous exchange of $C$. welensii individuals with neighboring areas, suggesting a host-selection mechanism that could mediate these movements. $C$. welensii has been found to show antennal sensitivity to limonene, myrcene, and pinene-type compounds (Sánchez-Osorio 2005). Nevertheless, monoterpenes (in particular, $\beta$-pinene) have been found to produce a low attraction of $C$. welensii to traps, compared with highrelease-rate synthetic blends mimicking fermenting plant material (Snchez-Osorio et al. 2016).

Our experimental design did not allow us to establish a causal relationship between $C$. welensii activity and monoterpene emission, as the influence of $C$. welensii colonization on emissions was not the primary focus of this study. Moreover, other attractive compounds (ethanol and other compounds from decaying tissues and bark exudates) could act either alone or in combination with foliar emissions. Nonetheless, the differences we found in the presence of the two main emission profiles (limonene-type and pinene-type) between infested and non-infested trees, especially during the early evening period, point to the influence of the emission profile on host choice by an insect with crepuscular flight activity. Moreover, the low emission rates we found in the late evening period suggest that the key time for discriminating between trees via monoterpene detection is the early evening period, near dusk, when $C$. welensii adults become active.

\section{Conclusion}

This study has evidenced differences in foliar monoterpene emission between $Q$. suber trees highly infested by the woodborer $C$. welensii and neighboring cork oak trees free of this cerambycid, in both daytime and early evening periods. Limonene dominated in trees infested by $C$. welensii, whereas pinene-type compounds did in non-infested trees. Given these results, we hypothesize that the detection - especially during the time when $C$. welensii adults initiate daily flight - of certain compounds (e.g., limonene), together with the detection of specific ratios of several monoterpenes (e.g., those of limonene to pinene-type compounds), has a role in the intraspecific host selection by $C$. welensii. These results contribute to understand plant-insect interactions, specifically those affecting host selection by $C$. welensii in $Q$. suber stands and may have important implications in the integrated and sustained pest management of this species. Further research should be warranted to assess the way changes in physiological performance of $Q$. suber (due to both woodborer damage and environmental stress) influence the emission behavior and the suitability of trees for $C$. welensii larval development, as well as to test the effect of some monoterpenes (mainly, limonene and pinene-type compounds, especially when they are combined with either moderate- or high-release-rate synthetic blends) on the attraction of $C$. welensii in laboratory and the field studies. Additional studies, using artificially baited trees and/or artificially weakened trees without larval activity, could be also warranted to assess whether emissions affect host selection.

Acknowledgments We thank Sebastiana Malia, Agustín Rincón, and María del Mar González for their assistance in both the field and the laboratory, and Dr. Manuel Fernández for his constructive comments.

Statement on data availability The datasets generated and/or analyzed during the current study are available in the Open Science Framework (Snchez-Osorio et al. 2019) at https://doi.org/10.17605/OSF.IO/D2ZH3.

\section{Compliance with ethical standards}

Conflict of interest The authors declare that they have no conflict of interest.

\section{References}

Alejano R, Domingo JM, Fernández M (coords) (2011) Manual para la gestión sostenible de las dehesas andaluzas. Foro para la Defensa y Conservación de la Dehesa "Encinal". Universidad de Huelva

Allison JD, Borden JH, Seybold JH (2004) A review of the chemical ecology of the Cerambycidae. Coleoptera 14:123-150

Aronson J, Pereira JS, Pausas JG (eds) (2009) Cork oak woodlands on the edge. Ecology, adaptive management, and restoration. Society for Ecological Restoration International, Island Press, Washington

Bates D, Maechler M, Bolker B, Walker S (2014) lme4: linear mixedeffects models using Eigen and S4_. R package version 1.1-7. http:// CRAN.R-project.org/package $=1 \mathrm{me} 4>$

Falconer DS, Mackay TFC (1996) Introduction to quantitative genetics, fourth ed. Longman Group Limited, Harlow

Grote R (2007) Sensitivity of volatile monoterpene emission to changes in canopy structure: a model-based exercise with a process-based emission model. New Phytol 173:550-561

ICNF (2013) IFN6 - Áreas dos usos do solo e das espécies florestais de Portugal continental. Resultados preliminares Instituto da Conservação da Natureza e das Florestas, Lisboa, 34 pp

Lavoir AV, Duffet C, Mouillot F, Rambal S, Ratte JP, Schnitzler JP, Staudt M (2011) Scaling-up leaf monoterpene emissions from a water limited Quercus ilex woodland. Atmos Environ 45:2888-2897

Lenth RV (2014) lsmeans: least-squares means. R package version 2.10.http://CRAN.R-project.org/package=lsmeans

López-Pantoja G, DomínguezNevado L, Sánchez-Osorio I (2008) Markrecapture estimates of the survival and recapture rates of Cerambyx welensii Küster (Coleoptera Cerambycidae) in a cork oak dehesa in Huelva (Spain). Cent Eur J Biol 3:431-441

Loreto F, Pollastri S, Fineschi S, Velikovac V (2014) Volatile isoprenoids and their importance for protection against environmental constraints in the Mediterranean area. Environ Exp Bot 103:99-106

Maja MM, Kasurinen A, Yli-Pirilä P, Joutsensaari J, Klemola T, Holopainen T, Holopainen JK (2014) Contrasting responses of 
silver birch VOC emissions to short- and long-term herbivory. Tree Physiol 34:241-252. https://doi.org/10.1093/treephys/tpt127

Martín J, Cabezas J, Buyolo T, Patón D (2005) The relationship between Cerambyx spp. damage and subsequent Biscogniauxia mediterranum infection on Quercus suber forests. For Ecol Manag 216:166-174

Millar JG, Hanks LM (2017) Chemical ecology of cerambycid beetles. In: Wang Q (ed) Cerambycidae of the world: biology and management. CRC Press/Taylor \& Francis, Boca Raton

Niinemets U, Seufert G, Steinbrecher R, Tenhunen JD (2002) A model coupling foliar monoterpene emissions to leaf photosynthetic characteristics in Mediterranean evergreen Quercus species. New Phytol $153: 257-275$

Niinemets U, Kännaste A, Copolovici L (2013) Quantitative patterns between plant volatile emissions induced by biotic stresses and the degree of damage. Front Plant Sci 4:262. https://doi.org/10.3389/ fpls.2013.00262

Núñez L, Plaza J, Pérez-Pastor R, Pujadas M, Gimeno B, Bermejo V, García-Alonso S (2002) High water vapour pressure deficit influence on Quercus ilex and Pinus pinea field monoterpene emission in the central Iberian Peninsula (Spain). Atmos Environ 36:4441-4452

Oksanen F, Blanchet G, Kindt R et al. (2015) Vegan: community ecology package. R package version 2.2-1.http://CRAN.R-project.org/ package $=$ vegan

Pio CA, Silva PA, Cerqueira MA, Nunes TV (2005) Diurnal and seasonal emissions of volatile organic compounds from cork oak (Quercus suber) trees. Atmos Environ 39:1817-1827

Sallé A, Nageleisen LM, Lieutier F (2014) Bark and wood boring insects involved in oak declines in Europe: current knowledge and future prospects in a context of climate change. For Ecol Manag 328:7993. https://doi.org/10.1016/j.foreco.2014.05.027

Sánchez-Osorio I (2005) Orientación olfativa de Cerambyx welensii Küster y Prinobius germari Dejean, principales cerambícidos xilófagos de encina (Quercus ilex L. subsp. ballota) y alcornoque (Quercus suber L.), para la localización de hospedantes. Doctoral Thesis, University of Huelva, Huelva

Sánchez-Osorio I, López-Pantoja L, Paramio AM, Lencina JL, Gallego D, Domínguez L (2016) Field attraction of Cerambyx welensii to fermentation odors and host monoterpenes. J Pest Sci 89:59-68

Sánchez-Osorio I, López-Pantoja G, Tapias R, Pareja-Sánchez E, Domínguez L (2019). Monoterpene emission of Quercus suber L. highly infested by Cerambyx welensii Küster. V 20 Aug 2019. Open Science Framework [Dataset] https://doi.org/10.17605/OSF.IO/ D2ZH3

Staudt M, Mir C, Joffre R, Rambal S, Bonin A, Landais D, Lumaret R (2004) Isoprenoid emission of Quercus spp. (Q. suber and Q. ilex) in mixed stands contrasting in interspecific genetic introgression. New Phytol 163:573-584

Tiberi R, Branco M, Bracalini M, Croci F, Panzavolta T (2016) Cork oak pests: a review of insect damage and management. Ann For Sci 73: 219-232. https://doi.org/10.1007/s13595-015-0534-1

Torres-Vila LM, Sanchez-González A, Ponce-Escudero F, MartínVertedor D, Ferrero-García JJ (2012) Assessing mass trapping efficiency and population density of Cerambyx welensii Küster by mark-recapture in dehesa open woodlands. Eur J Forest Res 131: 1103-1116. https://doi.org/10.1007/s10342-011-0579-0

Torres-Vila LM, Mendiola-Diaz FJ, Conejo-Rodríguez Y, SánchezGonzález Á (2016) Reproductive traits and number of matings in males and females of Cerambyx welensii (Coleoptera: Cerambycidae) an emergent pest of oaks. Bull Entomol Res 106: 292-303

Torres-Vila LM, Mendiola-Díaz FJ, Sánchez-González Á (2017) Dispersal differences of a pest and a protected Cerambyx species (Coleoptera: Cerambycidae) in oak open woodlands: a mark-recapture comparative study. Ecol Entomol 42:18-32. https://doi.org/10. 1111/een.12355

Vives E (2000) Coleoptera, Cerambycidae. Fauna Ibérica, vol 12 (ed. by M. A Ramos et al.), Museo Nacional de CienciasNaturales. CSIC, Madrid

Zhang Q-H, Birgersson G, Zhu J, Lofstedt C, Lofqvist J, Schlyter F (1999) Leaf volatiles from nonhost deciduous trees: variation by tree species, season and temperature, and electrophysiological activity in Ips typographus. J Chem Ecol 8:1923-1943

Publisher's note Springer Nature remains neutral with regard to jurisdictional claims in published maps and institutional affiliations. 